\title{
Dual Tweezer Behavior of an Octapodal Pyrene Porphyrin-based System as a Host for Fullerenes
}

\author{
Sergio Ferrero, Héctor Barbero, Daniel Miguel, Raúl García-Rodríguez* and Celedonio M. Álvarez* \\ GIR MIOMeT, IU CINQUIMA/Química Inorgánica, Facultad de Ciencias, Universidad de Valladolid, E-47011, Valladolid, \\ Spain
}

Supporting Information Placeholder

\begin{abstract}
The incorporation of eight pyrene units in a single porphyrin core exhibits a great synergistic effect, resulting in high affinity towards $\mathrm{C}_{60}$ and $\mathrm{C}_{70}$. This octapyrene porphyrin is easily accessible by a straightforward two-step synthetic approach that involves an octuple Suzuki reaction. The new supramolecular platform can present single or double tweezer fullerene hosting behavior. The switch from double to single tweezer behaviour is triggered by the simple coordination of $\mathrm{Zn}^{2+}$ to the porphyrin. Both the octa-pyrene porphyrin 2HPOP and its zinc metalloporphyrin analogue ZnPOP show very high affinity for $\mathrm{C}_{60}$ and $\mathrm{C}_{70}$, while simultaneously allowing the discrimination of $\mathrm{C}_{70}$ over $\mathrm{C}_{60}$ in a $\mathrm{C}_{60} / \mathrm{C}_{70}$ mixture. The use of 2HPOP and ZnPOP for the enrichment of real fullerene mixtures is also demonstrated.
\end{abstract}

\section{INTRODUCTION}

Intermolecular $\pi-\pi$ interactions are one of the main driving forces responsible for controlling supramolecular chemistry in carbon nanostructures. ${ }^{1}$ In this regard, shape complementarity between the different nanostructures is known to play a major role. It is also widely accepted that good interaction with $\mathrm{C}_{60}$ or $\mathrm{C}_{70}$ requires non-planar structures, ${ }^{2}$ and in this context non-planar polycyclic aromatic hydrocarbons (PAHs), such as the unique bowl-shaped corannulene-based systems, have emerged as very important. ${ }^{3}$ On the other hand, systems based on the planar PAH pyrene are ideally suited for interaction with more extended structures such as carbon nanotubes ${ }^{4}$ and graphene. ${ }^{5}$ Not surprisingly, only a few examples of pyrene-fullerene interactions have been reported, ${ }^{6}$ most of them involving the design of complex molecular cages. ${ }^{7}$ In contrast with non-planar PAH-based approaches, ${ }^{8}$ no discrimination between $\mathrm{C}_{60}$ and $\mathrm{C}_{70}$ has been reported for pyrene-based systems. This is quite surprising, since current supramolecular approaches require more complex scaffolds based on non-planar PAHs such as corannulene moieties ${ }^{9}$ which are not easily synthetically accessible. Achieving a good balance between facile synthesis and a high affinity constant, and in particular the ability to achieve discrimination, still remains challenging. Therefore, the development of cheaper and more synthetically accessible pyrene-based systems is an attractive but difficult task.

In the search for new molecular architectures that act as hosts for fullerenes, researchers have focused on porphyrin-based systems. Although porphyrins are known to interact with fullerenes and co-crystallization adducts have been extensively reported, ${ }^{10}$ 
for a single core porphyrin, this interaction is usually too weak to be observed in solution. ${ }^{10 a, 10 c, 11}$ Therefore, in order to achieve high affinity constants, the preparation of multiporphyrinic cages is required. ${ }^{12}$ Considerable efforts have been devoted to the tailoring of such complex systems to improve the interaction with fullerenes. Although this approach has been shown to provide some remarkably high affinities towards fullerenes, including selectivity for $\mathrm{C}_{70}$ over $\mathrm{C}_{60},{ }^{11 a}, 12-13$ their complex, multistep, and tedious syntheses prevent this approach from becoming general for fullerene interaction and discrimination. We have recently shown that easily accessible porphyrins based on a meso-susbtituted tetraaryl porphyrin core bearing different PAH units could be used for $\mathrm{C}_{60}$ hosting. ${ }^{14}$ The corannulene-based system, which contained four corannulene units, showed a remarkably high affinity constant $\left(\mathrm{K}_{\mathrm{a}}=2.2 \times 10^{4} \mathrm{M}^{-1}\right)$ for the $\alpha_{4}$ atropoisomer, presenting a 1:1 binding stoichiometry. One distinct limitation, however, was that the formation of atropisomers, whose separation was not possible, not only resulted in a complex and difficult-to-analyse mixture of species, but also diminished the interaction with $\mathrm{C}_{60}$.

Herein, we report the first example of a single core porphyrin that discriminates $\mathrm{C}_{70}$ over $\mathrm{C}_{60}$ in a fullerene mixture. The system is based on the simultaneous introduction of eight commercially available planar PAH pyrene moieties at the meta positions on a tetraaryl porphyrin system. This not only avoids the formation of atropisomers, but also results in a great synergistic effect between the porphyrin core and the pyrene units (Figure 1). This approach avoids the use of less synthetically and commercially accessible systems, such as those based on non-planar PAHs like corannulene, and also introduces the possibility for the system to act as a single or a double-tweezer structure as a host for fullerenes. This particular behaviour stems from the arrangement of four pyrene arms above and four below the porphyrin ring plane, resulting in a 'double picket fence’ porphyrin.

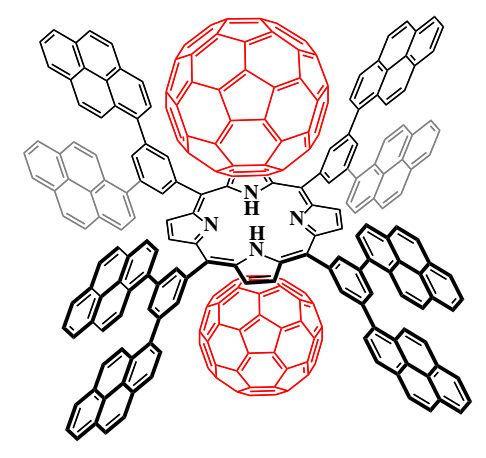

Figure 1. Idealized schematic representation of the tetraaryl octapyrene porphyrin reported in this work and its potential behavior as a double-tweezer structure to host fullerenes.

\section{RESULTS AND DISCUSSION}

As noted in the introduction, porphyrin systems are ideal scaffolds for constructing relatively complex molecular architectures. Although one unit of pyrene is known not to affect the recognition of fullerenes, we reasoned that fullerene recognition could be achieved through the cooperative effect of several units of pyrene on a porphyrin core. We sought to introduce two pyrene moieties at the meta position of an aryl group of a symmetrically substituted meso tetraaryl porphyrin to yield an octapyrene-based system (Figure 1). In such a system, the formation of atropisomers is prevented and the pyrene units would be ideally placed to 
interact with fullerenes in a cooperative manner thanks to the particular arrangement provided by the central scaffold. This, along with the great synergistic effect between the porphyrin core and the pyrene units, would result in a simple but effective platform for fullerene hosting. In addition to this, the $4+4$ arrangement of the pyrene arms in the “up” and "down” positions with regards to the porphyrin plane could allow the system to act as a double molecular tweezer for which 1:2 supramolecular interactions could occur.

We envisaged that such a system could be easily prepared in a two-step synthesis following the so-called “divergent” approach, in which a suitable porphyrin core with functionalities that can be subsequently used as reactive points for the construction of a more complex scaffold is first prepared. Our initial attempts involving the reaction of the meta-substituted octaboronateporphyrin compound $\mathbf{2 H P O B}$ and 1-bromopyrene resulted in an extremely low yield (less than 1\%) for the octa Suzuki reaction (see SI, route 2). However, this could be easily circumvented by employing the meta substituted octabromo-porphyrin $\mathbf{2 H P O B r}$ as the starting porphyrin core (Scheme 1). The synthesis of this compound was easily accomplished in 15 min by a MW-assisted method in which 2HPOBr cleanly precipitates from the reaction mixture (see experimental section). This approach drastically improved the yield (24\%) compared to that of the previously existing method (11\%), which required of $48 \mathrm{~h}$ of reflux in propionic acid and purification by chromatography. ${ }^{15}$ With this compound in hand, the target compound $2 \mathbf{H P O P}$ was obtained via a MW-assisted octuple Suzuki reaction. The use of a MW reactor is critical for the success of the reaction, as it is known to drastically decrease the amount of undesired byproducts. ${ }^{16}$ This can be easily realised from the remarkably high total yield of $28 \%$ (i.e., more than $85 \%$ per single cross-coupling reaction) and the fact that similar reactions involving a high number of Pdcatalysed C-C couplings are known to be problematic due to the rapid build-up of by-products, which can completely prevent product formation. ${ }^{17}$ Metallation of $\mathbf{2 H P O P}$ with $\mathrm{Zn}(\mathrm{OAc})_{2} \cdot 2 \mathrm{H}_{2} \mathrm{O}$ to give $\mathbf{Z n P O P}$ (Scheme 1) was straightforwardly achieved in a quantitative manner, thus providing an additional platform for fullerene hosting and also for evaluating the impact of the introduction of a metal on the supramolecular binding behaviour. It is known that metal insertion can lead to remarkable changes in the geometry of the central ring of the porphyrin ${ }^{18}$ and provide a new set of noncovalent interactions ${ }^{10 a, 11 a, 19}$, both of which may lead to a change in the hosting behaviour of the system.

Scheme 1 Optimized synthesis of 2HPOP and ZnPOP ${ }^{a}$

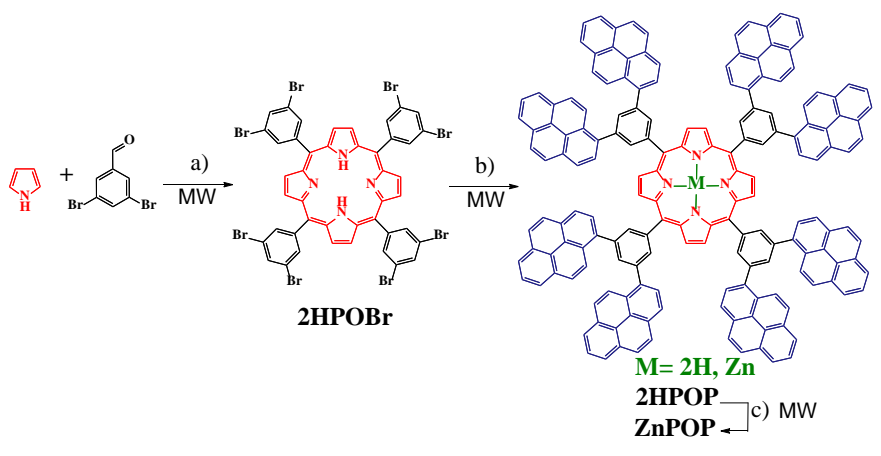

${ }^{\mathrm{a}}$ Reagents and conditions: (a) propionic acid, nitrobenzene, MW, $200{ }^{\circ} \mathrm{C}$; (b) Bpin-Pyrene (1), $\left[\mathrm{PdCl}_{2}(\mathrm{dppf})\right],{ }^{\mathrm{t}} \mathrm{BuONa}$, toluene, $\mathrm{MW}$, (c) $\mathrm{Zn}(\mathrm{OAc})_{2} \cdot 2 \mathrm{H}_{2} \mathrm{O}, \mathrm{CHCl}_{3} /$ toluene, $\mathrm{MW}, 120^{\circ} \mathrm{C}$. 
All the aforementioned porphyrins were fully characterized by NMR spectroscopy, UV-Vis absorption spectroscopy and highresolution MALDI-TOF mass spectrometry (see the experimental part and SI). The UV-Vis absorption spectra in toluene display the expected weak Q-bands in the range 500-670 $\mathrm{nm}$ and the intense Soret bands, which are red-shifted for ZnPOP (432 nm) as compared to 2HPOP (428 nm). This small but distinctive red-shift of the band has been suggested to be related to an increase in the non-planarity of the porphyrin. ${ }^{18 \mathrm{~d}, 20}{ }^{1} \mathrm{H}$ NMR spectra of the octapyrene porphyrins $2 \mathbf{H P O P}$ and ZnPOP show the equivalency of the eight pyrene moieties resulting from the effective $\mathrm{D}_{4 \mathrm{~h}}$ symmetry in solution (see ${ }^{1} \mathrm{H}$ and ${ }^{13} \mathrm{C}\left\{{ }^{1} \mathrm{H}\right\}$ spectra in the SI). The presence of the two inner NH protons of $\mathbf{2 H P O P}$ is observed at a characteristic upfield shift of $\delta=-2.50$ ppm as a consequence of the shielding they experience from the aromatic ring current present in the porphyrin core. This signal is absent in the metallated porphyrin ZnPOP. It is worth mentioning the different behavior observed for $\mathbf{2 H P O P}$ and $\mathbf{Z n P O P}$ in $\mathrm{CDCl}_{3}$. While the ${ }^{1} \mathrm{H}$ NMR spectrum of 2HPOP exhibits sharp resonances for the range of concentrations studied $\left(10^{-4}-10^{-6} \mathrm{M}\right)$, ZnPOP shows very broad resonances in relatively dilute solutions $\left(10^{-5} \mathrm{M}\right)$ that become sharper with the further dilution of the sample (See SI, Figs S9). This behavior is indicative of an intermolecular process. ${ }^{21}$ However, both 2 HPOP and ZnPOP show non-concentrationdependent behavior in toluene- $\mathrm{d}_{8}$, a solvent that is known to disrupt intermolecular $\pi$ - $\pi$ stacking interactions. ${ }^{10 a, 21 a}$ This suggests that ZnPOP, unlike its unmetallated analogue 2HPOP, may undergo a certain degree of stacking due to $\pi$ - $\pi$ interactions between porphyrins in $\mathrm{CDCl}_{3}$. The extent to which the $\mathrm{Zn}$ centre directly contributes to the formation of these $\pi$ - $\pi$ stacking interactions is unknown at this stage.

We then moved to study the supramolecular behavior of ZnPOP and 2HPOP as hosts for $\mathrm{C}_{60}$ and $\mathrm{C}_{70}$. We were particularly interested in studying whether these porphyrin systems could act as a single or double tweezers (i.e., whether they could accept one or two fullerenes, as shown in Fig. 1). We initially used a host concentration of $[\mathrm{H}]_{0}=10^{-4}$ M. Although the titrations could be carried out for $\mathrm{C}_{60}$, the titration of ZnPOP and 2 HPOP with $\mathrm{C}_{70}$ was prevented by the appearance of a precipitate. This suggested a much larger affinity of both systems for $\mathrm{C}_{70}$ than for $\mathrm{C}_{60}$, for which no precipitate was observed. We therefore set the concentration of host to $[\mathrm{H}]_{0}=10^{-5} \mathrm{M}$ for the titration experiments involving $\mathrm{C}_{70}$. We started our studies with ZnPOP, and we carried out titration experiments with $\mathrm{C}_{60}$ and $\mathrm{C}_{70}$ in toluene- $\mathrm{d}_{8}$. In both experiments, we followed the shift of $\mathrm{H}_{8}$ (see figure 2 , S22 and S24 in the SI) during the titration. As shown in Figure 2 above, the chemical shift for $\mathrm{H}_{8}$ changes during the titration of ZnPOP with $\mathrm{C}_{60}$ or $\mathrm{C}_{70}$, indicating supramolecular association and host-guest formation in both cases. The non-linear binding isotherm that results from the titration experiments with $C_{60}$ or $C_{70}$ could be fitted, in both cases, to a 1:1 model (Fig. 2 below). No evidence for a 1:2 model in which ZnPOP accepts two fullerenes was observed. These plots clearly show a faster saturation for $\mathrm{C}_{70}$, which reaches the limiting chemical shift $\Delta \delta_{\max }$ much faster than $\mathrm{C}_{60}$, reflecting a greater binding constant value $\mathrm{K}_{\mathrm{a}}$ for ZnPOP and $\mathrm{C}_{70}$. The calculated binding constants of ZnPOP for $\mathrm{C}_{60}$ and $\mathrm{C}_{70}$ are $\mathrm{K}_{1}=2.30 \pm 0.01 \times 10^{3} \mathbf{M}^{-1}$ and $\mathrm{K}_{1}=$ $2.69 \pm 0.02 \times 10^{4} \mathrm{M}^{-1}$, respectively. This shows that ZnPOP has a very high selectivity, preferring $\mathrm{C}_{70}$ over $\mathrm{C}_{60}$, as demonstrated by the binding constant for $\mathrm{C}_{70}$, which is an order of magnitude larger than the one for $\mathrm{C}_{60}$. 

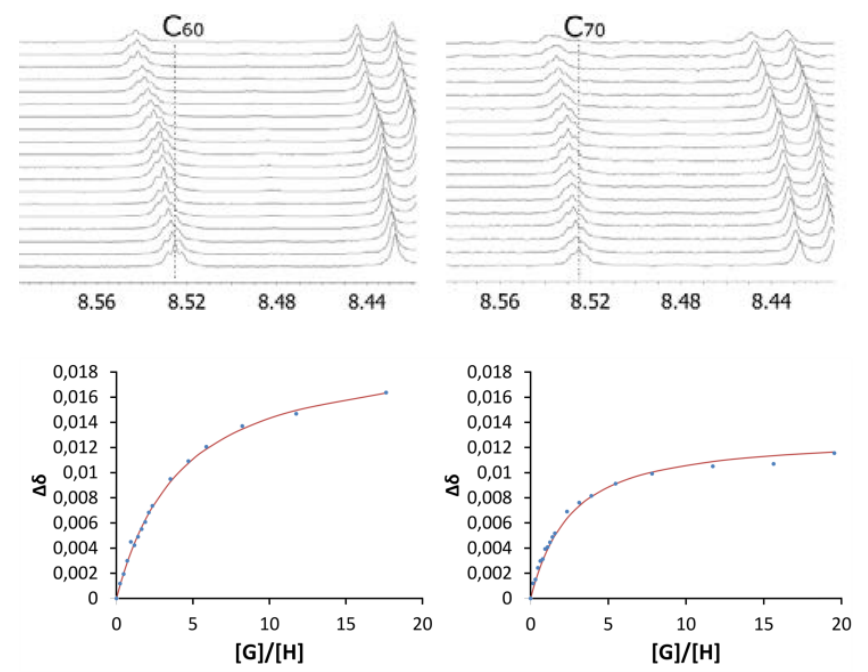

Figure 2. (Above) ${ }^{1} \mathrm{H}$ NMR spectra in toluene- $\mathrm{d}_{8}$ showing the $\mathrm{H}_{8}$ chemical shift of ZnPOP upon the addition of aliquots of $\mathrm{C}_{60}$ (left) or $\mathrm{C}_{70}$ (right). (Below). Plot of the changes in the chemical shift against $[\mathrm{G}] /[\mathrm{H}]$, where $\mathrm{G}$ (guest) is $\mathrm{C}_{60}$ or $\mathrm{C}_{70}$ and $\mathrm{H}$ (host) is $\mathbf{Z n P O P}$. The red line corresponds to the nonlinear fitting of $\Delta \delta$ for $\mathrm{H}_{8}$ to a $1: 1$ binding isotherm. It can be seen that the titration with $\mathrm{C}_{70}$ reaches supramolecular saturation earlier than $\mathrm{C}_{60}$, reflecting a larger binding constant. Note: $[\mathrm{H}]_{0}=10^{-4} \mathrm{M}$ for $\mathrm{C}_{60}$ titration and $[\mathrm{H}]_{0}=10^{-5} \mathrm{M}$ for $\mathrm{C}_{70}$. In sharp contrast, the titration of $\mathbf{2 H P O P}$ with $\mathrm{C}_{70}$ did not show the typical 1:1 binding isotherm observed for ZnPOP. Instead, a very complex behaviour was observed, indicative of a non-1:1 system. ${ }^{22}$ This complex behaviour was observed at different initial concentrations of the host, $[\mathrm{H}]_{0}$ (see figure S28 and S30 SI). Figure 3 shows the change of $\Delta \delta$ against [Guest]/[Host]. The graph shows two inflexion points at $[\mathrm{G}] /[\mathrm{H}]=1$ and $c a .[\mathrm{G}] /[\mathrm{H}]=2$. The binding isotherm could be fitted to a $1: 2$ noncooperative model for which the values $\mathrm{K}_{1}=1.40 \pm 0.05 \times 10^{4} \mathrm{M}^{-1}$ and $\mathrm{K}_{2}=3.50 \pm 0.13 \times 10^{3} \mathrm{M}^{-1}$ were obtained. $^{23}$ This double tweezer behaviour of $\mathbf{2 H P O P}$ was also observed for the interaction with $\mathrm{C}_{60}$. The binding isotherm observed in this case did not show such complex behaviour, but instead an asymptotic curve. This apparently simple behaviour could also be better explained by a $1: 2$ non-cooperative model $\left(\operatorname{cov}_{\text {fit }}=3.16\right)^{23 b}$ with $K_{1}=1.49 \pm 0.01 \times 10^{3} \mathrm{M}^{-1}$ and $\mathrm{K}_{2}=3.71 \pm 0.02 \times 10^{2} \mathrm{M}^{-1}$ (see SI for details), than by a 1:1 model as in the case of ZnPOP.

These results show that the selection between double/single tweezer behavior might be controlled by simply coordinating $\mathrm{Zn}^{2+}$ in the porphyrin, thus illustrating how subtle changes in the porphyrin skeleton may lead to drastic changes in their supramolecular behavior. 


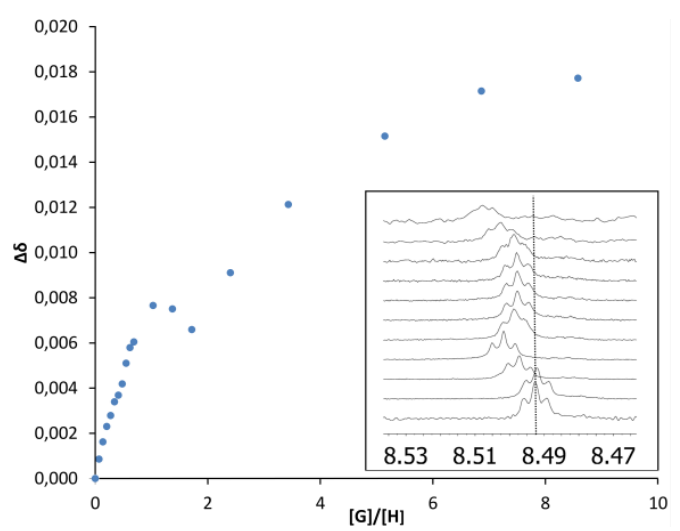

Figure 3. Plot of changes in the chemical shift of $\mathrm{H}_{8}$ against $[\mathrm{G}] /[\mathrm{H}]$, where $\mathrm{G}$ (guest) is $\mathrm{C}_{70}$ and $\mathrm{H}$ (host) is $\mathbf{2 H P O P}$, showing the more complex behaviour of the binding isotherm. $[\mathrm{H}]_{0}=10^{-5} \mathrm{M}$. Inset, stacked ${ }^{1} \mathrm{H}$ NMR spectra showing the variation of the $\mathrm{H}_{8}$ chemical shift of 2HPOP, $[\mathrm{H}]_{0}=10^{-4} \mathrm{M}$, upon the addition of aliquots of $\mathrm{C}_{70}$. Note: the dotted line is a guide to the eye.

Importantly, the great selectivity for $\mathrm{C}_{70}$ over $\mathrm{C}_{60}$ (one order of magnitude) is retained in the case of $\mathbf{2 H P O P}$ when switching from a single tweezer behaviour, as observed in ZnPOP, to a double tweezer one (Table 1). It is worth mentioning that the binding constants for both fullerenes are similar to those based on non-planar PAH systems bearing more complex corannulene motifs, whose bowl-shaped polycyclic aromatic hydrocarbon structure is known to provide complementarity between corannulenefullerene surfaces. ${ }^{8 b, 24}$ For instance, Sygula's buckycatcher with two corannulene pincers on a cyclooctatetraene framework

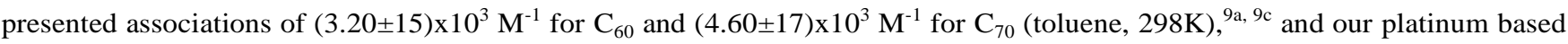

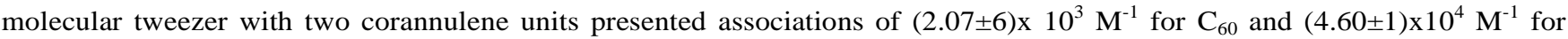
$\mathrm{C}_{70}$, the highest at the time for a corannulene based system (toluene, $\left.298 \mathrm{~K}\right){ }^{8 \mathrm{a}}$ As discussed in the introduction, our previously reported tetraaryl porphyrin core bearing four corannulene units in the para position showed a remarkably high affinity for $\mathrm{C}_{60}$ for its $\alpha_{4}$ atropoisomer $2.2 \times 10^{4} \mathrm{M}^{-1}$ (toluene, 298K). However the formation of atropoisomers drastically decreased the overall association ability of the system. ${ }^{14}$ This shows the great potential of our simple approach based on the two-step synthesis of a single porphyrin bearing eight pyrene units.

Table 1. Summary of Binding Constants $\mathrm{K}_{\mathrm{a}}\left(\mathrm{M}^{-1}\right)$ of $\mathbf{2 H P O P}$ and ZnPOP for $\mathrm{C}_{60}\left([\mathrm{H}]_{0}=10^{-4} \mathrm{M}\right)$ and $\mathrm{C}_{70}\left([\mathrm{H}]_{0}=10^{-5} \mathrm{M}\right)$ in Toluene- $\mathrm{d}_{8}$

\begin{tabular}{lll}
\hline & $\mathrm{C}_{60}$ & $\mathrm{C}_{70}$ \\
\hline ZnPOP & $\mathrm{K}_{1}=2.30 \pm 0.01 \times 10^{3}$ & $\mathrm{~K}_{1}=2.69 \pm 0.02 \times 10^{4}$ \\
\hline \multirow{2}{*}{ 2HPOP } & $\mathrm{K}_{1}=1.49 \pm 0.01 \times 10^{3}$ & $\mathrm{~K}_{1}=1.40 \pm 0.05 \times 10^{4}$ \\
& $\mathrm{~K}_{2}=3.71 \pm 0.02 \times 10^{2}$ & $\mathrm{~K}_{2}=3.50 \pm 0.13 \times 10^{3}$ \\
\hline
\end{tabular}

Having established that the switch from double to single tweezer behaviour is triggered by the simple coordination of $\mathrm{Zn}^{2+}$ to the porphyrin core, we then moved to evaluate the possibility of using these systems to separate/enrich a $\mathrm{C}_{60} / \mathrm{C}_{70}$ fullerene mixture by selectively sequestering $C_{70}$ from the solution. We were motivated to explore this possibility by the large selectivity for $C_{70}$ 
over $\mathrm{C}_{60}$ shown by ZnPOP and 2HPOP, as well as the low solubility of the adducts formed with $\mathrm{C}_{70}$, as noted above. We initially dissolved an equimolar amount of $\mathrm{C}_{60} / \mathrm{C}_{70}$ in toluene- $\mathrm{d}_{8}$ and recorded a ${ }^{13} \mathrm{C}\left\{{ }^{1} \mathrm{H}\right\}$ NMR spectrum ${ }^{25}$ (Figure 4, above). The addition of one equivalent of 2 HPOP resulted in the formation of the fullerene-porphyrin adduct as a black precipitate after sonication of the sample, which could be easily separated from the supernatant by simply decanting the solution. The ${ }^{13} \mathrm{C}\left\{{ }^{1} \mathrm{H}\right\}$ spectrum of the decanted supernatant shows a $\mathrm{C}_{70} / \mathrm{C}_{60}$ ratio of 1:2.7 (Figure 4, below), which was also verified by UV-Vis and HPLC. ${ }^{25 b, 26}$ Thus, a nearly three times more enriched sample of $\mathrm{C}_{60}$ was easily obtained by simply adding one equivalent of 2HPOP. The level of enrichment of $\mathrm{C}_{60}$ in solution was found to increase steadily with the addition of $\mathbf{2 H P O P}$. The addition of 0.7 eq and 1.6 eq to $1: 1$ mixtures of $C_{70} / C_{60}$ resulted in enrichment levels of 1:2.0 and 1:4.6 of $C_{60}$ in the solution, respectively, as analyzed by ${ }^{13} \mathrm{C}\left\{{ }^{1} \mathrm{H}\right\}$ NMR, UV-Vis and HPLC, with a loss of $42 \%$ of $\mathrm{C}_{60}$ as co-precipitate for the latter case (see SI).

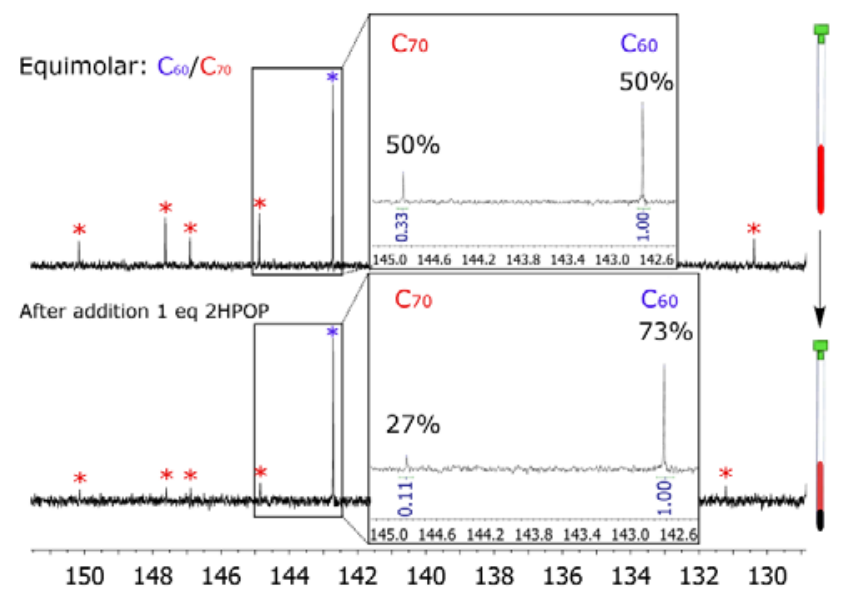

Figure 4. Quantitative ${ }^{13} \mathrm{C}\left\{{ }^{1} \mathrm{H}\right\}$ NMR spectra in toluene- $\mathrm{d}_{8}$ of an equimolar solution of $\mathrm{C}_{60} / \mathrm{C}_{70}$ before (above) and after (below) the addition of 1 equivalent of 2HPOP. Signals of $C_{70}$ are reduced as a result of its precipitation as the 2HPOP adduct of $\mathrm{C}_{70}$. Note: The 5 resonances for $\mathrm{C}_{70}$ are shown with red asterisks, and the one for $\mathrm{C}_{60}$ with a purple asterisk. The fullerene $\mathrm{C}_{60} / \mathrm{C}_{70}$ ratio was extracted from the integration of their signals considering their relative proportion of nuclei.

Encouraged by these good results, we turned our attention towards the use of ZnPOP for fullerene enrichment. We were intrigued to test whether we could improve the results obtained with $\mathbf{2 H P O P}$ and minimise the amount of $\mathrm{C}_{60}$ loss as coprecipitate. We found that the addition of 1 equivalent of ZnPOP to a 1:1 mixture of $\mathrm{C}_{70} / \mathrm{C}_{60}$ in toluene resulted in a 1:8.1 enrichment of $\mathrm{C}_{60}$ in solution, while only losing $13 \%$ of the initial amount of $\mathrm{C}_{60}$ by co-precipitation, thus improving the results obtained with 2HPOP. A distinctive difference in this case is that ZnPOP behaves as a single tweezer for fullerene recognition, while in the case of $\mathbf{2 H P O P}$ the loss of $\mathrm{C}_{60}$ as co-precipitate could be enhanced by its double tweezer behaviour. These results are still far from the best ones obtained with carefully designed porphyrin-based molecular cages. ${ }^{27}$ For example, Zhang et al designed a 3-D rectangular prismatic molecular cage displaying an astonishingly high separation of $\mathrm{C}_{70}$ from a $\mathrm{C}_{60}$-enriched fullerene mixture, with a 9-fold increase in the separation of $\mathrm{C}_{70}$ from a $\mathrm{C}_{60}$-enriched fullerene mixture (from 9 mol\% to 79 
mol\%). ${ }^{27 a}$ Nonetheless, our results show the generality of this approach to enrich fullerene mixtures in a simple and handy manner.

\section{CONCLUSIONS}

We have reported a two-step synthesis of a single porphyrin core system bearing 8 pyrene units that shows high affinity towards $\mathrm{C}_{60}$ and $\mathrm{C}_{70}$. The key to the success of our approach is the integration of 8 pyrene units in a tetraaryl meso-substituted porphyrin, which results in a great synergistic effect between the porphyrin core and the pyrene units. The resulting 'double picket fence' porphyrin can behave as either a double or single tweezer simply by the introduction of $\mathrm{Zn}^{2+}$ into the porphyrin core, which triggers the switch from double (2HPOP) to single (ZnPOP) tweezer behavior, thus allowing additional control of our supramolecular platform. In addition to this, ZnPOP and 2HPOP can discriminate between $\mathrm{C}_{70}$ and $\mathrm{C}_{60}$, and their use for the easy enrichment of $\mathrm{C}_{60} / \mathrm{C}_{70}$ mixtures of fullerenes is demonstrated. To the best of our knowledge, this constitutes the first example of discrimination between $\mathrm{C}_{60}$ and $\mathrm{C}_{70}$ using a pyrene-based molecular tweezer. This type of discrimination has generally been the domain of non-planar PAH systems that display greater shape complementarity or of complex molecular cages, but both designs are much more synthetically costly. Ongoing research in our labs is aimed at developing new octapodal non-planar PAH porphyrin-based systems for fullerene discrimination, as well as probing the exact mechanism of the single and double tweezer behaviour in these new and fascinating supramolecular systems.

\section{EXPERIMENTAL}

\section{General Methods}

All reagents were purchased from commercial sources and used without further purification. Solvents were either used as purchased or dried according to procedures described elsewhere. ${ }^{28}$ Microwave reactions were carried out using an Anton Paar Monowave 300 Reactor. Column chromatography was carried out using silica gel 60 (particle size 0.040-0.063 mm; 230-400 mesh) as the stationary phase, and TLC was performed on precoated silica gel plates (0.25 mm thick, 60 F254) and visualized under UV light and/or by immersion in anisaldehyde. NMR spectra and NMR titrations were recorded on 500 MHz Agilent DD2 instruments equipped with a coldprobe in the Laboratory of Instrumental Techniques (LTI) Research Facilities, University of Valladolid. Fullerene ${ }^{13} \mathrm{C}\left\{{ }^{1} \mathrm{H}\right\}$ NMR experiments were recorded on $500 \mathrm{MHz}$ Agilent instruments equipped with a ONEPROBE using the following acquisition parameters: $4 \mathrm{~s}$ relaxation delay between transients, $45^{\circ}$ pulse width, and $1.048 \mathrm{~s}$ acquisition time. ${ }^{1} \mathrm{H}$ and ${ }^{13} \mathrm{C}$. NMR chemical shifts $(\delta)$ are reported in parts per million (ppm) and are referenced to TMS, using the solvent as an internal reference. Coupling constants $(J)$ are reported in Hz. Standard abbreviations are used to indicate multiplicity: s $=$ singlet, $\mathrm{d}=$ doublet, $\mathrm{t}=$ triplet, $\mathrm{m}=$ multiplet. ${ }^{1} \mathrm{H}$ and ${ }^{13} \mathrm{C}$ peak assignments were performed using $2 \mathrm{D}$ NMR methods (DQFCOSY, band selective ${ }^{1} \mathrm{H}-{ }^{1} \mathrm{H}-$ ROESY, band selective ${ }^{1} \mathrm{H}_{-}{ }^{13} \mathrm{C}$ HSQC, band selective ${ }^{1} \mathrm{H}_{-}{ }^{13} \mathrm{C}$ HMBC). Due to low solubility, some carbon signals were detected indirectly via ${ }^{1} \mathrm{H}-{ }^{13} \mathrm{C}-\mathrm{HMBC}$ experiments; in these cases, the abbreviation in is used. High resolution mass spectra were recorded at the mass spectrometry service of the Laboratory of Instrumental Techniques (LTI) of the University of Valladolid. A MALDI-TOF system (MALDI-TOF), the Bruker Autoflex Speed $\left(\mathrm{N}_{2}\right.$ laser: $337 \mathrm{~nm}$, pulse energy $100 \mu \mathrm{J}, 1 \mathrm{~ns}$; 
acceleration voltage: $19 \mathrm{kV}$, reflector positive mode) was used. Trans-2-[3-(4-tert-butylphenyl)-2-methyl-2propenylidene]malonitrile (DCTB) and 1,8,9-anthracenetriol, 1,8-dihydroxy-9(10H)-anthracenone (dithranol) were used as matrixes. UV/Vis spectra were recorded using a Shimadzu UV-1603 with spectrophotometric grade solvents. UV/vis absorption spectral wavelengths $(\lambda)$ are reported in nanometers $(\mathrm{nm})$, and molar absorption coefficients $(\varepsilon)$ are reported in $\mathrm{M}^{-1} \mathrm{~cm}^{-1} . \mathrm{High}$ performance liquid chromatography (HPLC) was performed at the chromatography service of the Laboratory of Instrumental Techniques (LTI) of the University of Valladolid using an Agilent 1200 Series with a C18 column $(4.6 \mathrm{~mm} \times 250 \mathrm{~mm}) \mathrm{with}$ a UV/Vis $(333 \mathrm{~nm})$ detector. The mobile phase was toluene/methanol/acetonitrile (60:20:20) containing $0.1 \%$ trifluoroacetic acid (TFA) at $30^{\circ} \mathrm{C}$.

\section{Pinacol pyreneboronate (1)}

1-pyreneboronic acid (100 mg, $0.406 \mathrm{mmol})$ and pinacol (72.3 $\mathrm{mg}, 0.609 \mathrm{mmol})$ were placed into a sealed vessel specifically designed for microwave irradiation. Initially, the mixture was heated inside a microwave reactor at $140{ }^{\circ} \mathrm{C}$ without stirring, allowing pinacol to melt, and then stirred for $15 \mathrm{~min}$. The mixture was dissolved in $20 \mathrm{ml}$ of DCM and placed into a separatory funnel with $20 \mathrm{ml}$ of warm $\mathrm{H}_{2} \mathrm{O}$. The organic phase was washed with $20 \mathrm{ml}$ of warm $\mathrm{H}_{2} \mathrm{O}$ twice, and the aqueous phase was extracted with $10 \mathrm{ml}$ of DCM. The organic layer was dried with anhydrous $\mathrm{MgSO}_{4}$, filtered and concentrated to afford $\mathbf{1}$ as a pure white solid (128 mg, 96\%). The spectroscopic data were in agreement with those reported in the literature. ${ }^{29}$

\section{$2 \mathrm{HPOBr}$}

Pyrrole (139 $\mu \mathrm{L}, 2 \mathrm{mmol})$, 3,5-dibromobenzaldehyde (557 mg, $2 \mathrm{mmol}$ ), propionic acid (7 mL, 87 mmol) and nitrobenzene (13 $\mathrm{mL}, 126 \mathrm{mmol}$ ) were mixed in a sealed vessel specifically designed for microwave irradiation. The mixture was stirred inside a microwave reactor at $200{ }^{\circ} \mathrm{C}$ for $15 \mathrm{~min}$; the pressure reached up to 4 bar. The dark crude was stored in a refrigerator for 2 days and then filtered in a Büchner funnel and washed with $\mathrm{MeOH}$. The obtained solid was placed in an oven and kept under reduced pressure $\left(200{ }^{\circ} \mathrm{C}, 3 \mathrm{~h}, 90\right.$ torr) to remove residual nitrobenzene and finally give the dark purple solid $2 \mathbf{H P O B r}(150 \mathrm{mg}, 24 \%$ yield). ${ }^{1} \mathrm{H}$ NMR (500 MHz, Chloroform-d): $\delta 8.89\left(\mathrm{~s}, 8 \mathrm{H}, \mathrm{H}_{2}\right), 8.31$ (d, $\left.J=1.8 \mathrm{~Hz}, 8 \mathrm{H}, \mathrm{H}_{6}\right), 8.15\left(\mathrm{t}, J=1.8 \mathrm{~Hz}, 4 \mathrm{H}, \mathrm{H}_{8}\right),-2.99$ (br, 2H, $\left.\mathrm{H}_{1}\right) \cdot{ }^{13} \mathrm{C}\left\{{ }^{1} \mathrm{H}\right\}$ NMR (126 MHz, Chloroform-d): $\delta 144.9\left(\mathrm{C}_{5}\right), 135.9\left(\mathrm{C}_{6}\right), 133.9\left(\mathrm{C}_{8}\right), 121.6\left(\mathrm{C}_{7}\right), 117.6\left(\mathrm{C}_{4}-\mathrm{in}\right) . \mathrm{HRMS}$ $\left(\right.$ MALDI-TOF) m/z: $[\mathrm{M}+\mathrm{H}]^{+}$Calcd for $\mathrm{C}_{44} \mathrm{H}_{22} \mathrm{Br}_{8} \mathrm{~N}_{4}$ 1246.5310; Found 1246.5311 (0.1 ppm error). UV/vis (toluene): $\lambda 402(\varepsilon=$ 33259), $422(\varepsilon=164714), 515(\varepsilon=8578), 545(\varepsilon=2507), 587(\varepsilon=2639)$.

\section{HPOP}

2HPOBr (10 mg, $0.0080 \mathrm{mmol})$, pinacol pyreneboronate (1) (23.3 mg, $0.071 \mathrm{mmol}),\left[\mathrm{PdCl}_{2}(\mathrm{dppf})\right]$ (9.3 mg, $\left.0.0128 \mathrm{mmol}\right)$ and ${ }^{\mathrm{t}} \mathrm{BuONa}$ (18.5 mg, $0.192 \mathrm{mmol}$ ) were mixed in a sealed vessel specifically designed for microwave irradiation and put the microwave reactor inside a two-necked round-bottom flask in order to keep the system under an inert atmosphere. 1.4 ml of dry toluene was added. The mixture was stirred inside a microwave reactor at $150{ }^{\circ} \mathrm{C}$ for 135 min (the pressure reached up to 3.8 bar). After cooling, the solvent was removed under vacuum and the crude was purified by column chromatography on silica gel, 
using hexane/AcOEt gradient elution (3:1- 2:1 - 1:1) and $\mathrm{CHCl}_{3}$ to finally give a purple solid $2 \mathbf{H P O P}\left(5.0 \mathrm{mg}, 28 \%\right.$ yield). ${ }^{1} \mathrm{H}$ NMR (500 MHz, Chloroform-d) $\delta: 9.46\left(\mathrm{~s}, 8 \mathrm{H}, \mathrm{H}_{2}\right), 8.85$ (d, $\left.J=9.3 \mathrm{~Hz}, 8 \mathrm{H}, \mathrm{H}_{10}\right), 8.73\left(\mathrm{~d}, J=1.7 \mathrm{~Hz}, 8 \mathrm{H}, \mathrm{H}_{6}\right), 8.46(\mathrm{~d}, J=7.9$ $\mathrm{Hz}, 8 \mathrm{H}, \mathrm{H}_{18}$ ), 8.42 (t, $J=1.7 \mathrm{~Hz}, 4 \mathrm{H}, \mathrm{H}_{8}$ ), 8.31 (d, $\left.J=7.9 \mathrm{~Hz}, 8 \mathrm{H}, \mathrm{H}_{17}\right), 8.19-8.15\left(\mathrm{~m}, 16 \mathrm{H}, \mathrm{H}_{14}+\mathrm{H}_{11}\right), 8.12-8.07(\mathrm{~m}, 16 \mathrm{H}$, $\mathrm{H}_{13}+\mathrm{H}_{12}$ ), 8.05 (d, $\left.J=7.7 \mathrm{~Hz}, 8 \mathrm{H}, \mathrm{H}_{16}\right), 7.94$ (t, $\left.J=7.7 \mathrm{~Hz}, 8 \mathrm{H}, \mathrm{H}_{15}\right),-2.50$ (br, 2H, $\left.\mathrm{H}_{1}\right) .{ }^{13} \mathrm{C}\left\{{ }^{1} \mathrm{H}\right\}$ NMR (126 MHz, Chloroformd) $\delta: 142.4\left(\mathrm{C}_{5}\right), 139.8\left(\mathrm{C}_{19}\right), 136.9\left(\mathrm{C}_{7}\right), 136.0\left(\mathrm{C}_{6}\right), 132.2\left(\mathrm{C}_{8}\right), 131.4\left(\mathrm{C}_{22}\right), 130.8\left(\mathrm{C}_{24}+\mathrm{C}_{20}\right), 128.7\left(\mathrm{C}_{9}\right), 128.1\left(\mathrm{C}_{18}\right), 127.9$ (C 11$), 127.5\left(\mathrm{C}_{13}\right), 127.3\left(\mathrm{C}_{12}\right), 125.9\left(\mathrm{C}_{15}\right), 125.1\left(\mathrm{C}_{14}\right), 125.05\left(\mathrm{C}_{10}\right), 125.01\left(\mathrm{C}_{\mathrm{q}}\right), 124.9\left(\mathrm{C}_{16}\right), 124.82\left(\mathrm{C}_{17}\right), 124.80\left(\mathrm{C}_{\mathrm{q}}\right), 120.1$ $\left(\mathrm{C}_{4}\right)$. HRMS (MALDI-TOF) m/z: [M+H $]^{+}$Calcd for $\mathrm{C}_{172} \mathrm{H}_{94} \mathrm{~N}_{4} 2214.7473$; Found 2214.7424 (-4.9 ppm error). UV/vis (toluene): $\lambda 280(\varepsilon=275508), 350(\varepsilon=238277), 410(\varepsilon=106537), 428(\varepsilon=503476), 518(\varepsilon=25202), 551(\varepsilon=12601)$.

\section{ZnPOP}

2HPOP (5.0 mg, $0.0022 \mathrm{mmol})$ and $\mathrm{Zn}(\mathrm{AcO})_{2} \cdot 2 \mathrm{H}_{2} \mathrm{O}(7.2 \mathrm{mg}, 0.033 \mathrm{mmol})$ were mixed in a sealed vessel specifically designed for microwave irradiation and a mixture of $1.5 \mathrm{ml}$ of $\mathrm{CHCl}_{3} / 1.5 \mathrm{ml}$ of toluene was added. The mixture was stirred inside a microwave reactor at $120^{\circ} \mathrm{C}$ for 90 min (the pressure reached up to $4.7 \mathrm{bar}$ ). After cooling, the solvent was removed under vacuum and the solid obtained was dissolved in $10 \mathrm{ml}$ of $\mathrm{CHCl}_{3}$ and placed into a separatory funnel and washed with $5 \mathrm{ml}$ of $\mathrm{H}_{2} \mathrm{O}$. The organic layer was removed under low pressure to give a purple solid ZnPOP (4.5 mg, 91\%). ${ }^{1} \mathrm{H}$ NMR (500 MHz, Chloroform- ) $\delta: 9.56\left(\mathrm{~s}, 8 \mathrm{H}, \mathrm{H}_{2}\right), 8.85\left(\mathrm{~d}, J=9.5 \mathrm{~Hz}, 8 \mathrm{H}, \mathrm{H}_{10}\right), 8.71\left(\mathrm{~d}, J=0.7 \mathrm{~Hz}, 8 \mathrm{H}, \mathrm{H}_{6}\right), 8.45\left(\mathrm{~d}, J=8.0 \mathrm{~Hz}, 8 \mathrm{H}, \mathrm{H}_{18}\right), 8.40(\mathrm{t}, J=0.7 \mathrm{~Hz}$, 4H, $\mathrm{H}_{8}$ ), 8.28 (d, $\left.J=8.0 \mathrm{~Hz}, 8 \mathrm{H}, \mathrm{H}_{17}\right), 8.17-8.12\left(\mathrm{~m}, 16 \mathrm{H}, \mathrm{H}_{14}+\mathrm{H}_{11}\right), 8.11-8.04\left(\mathrm{~m}, 16 \mathrm{H}, \mathrm{H}_{13}+\mathrm{H}_{12}\right), 7.99\left(\mathrm{br}, 8 \mathrm{H}, \mathrm{H}_{16}\right), 7.90$ (br, 8H, $\left.\mathrm{H}_{15}\right) .{ }^{13} \mathrm{C}\left\{{ }^{1} \mathrm{H}\right\}$ NMR (126 MHz, Chloroform-d) $\delta: 150.3\left(\mathrm{C}_{3}\right), 143.2\left(\mathrm{C}_{5}\right), 139.5\left(\mathrm{C}_{19}\right), 137.1\left(\mathrm{C}_{7}\right), 136.0\left(\mathrm{C}_{6}\right), 132.3\left(\mathrm{C}_{2}\right)$, $131.8\left(\mathrm{C}_{8}\right), 131.2\left(\mathrm{C}_{22}\right), 130.7\left(\mathrm{C}_{24}+\mathrm{C}_{20}\right), 128.7\left(\mathrm{C}_{9}\right), 128.0\left(\mathrm{C}_{18}\right), 127.7\left(\mathrm{C}_{11}\right), 127.4\left(\mathrm{C}_{13}\right), 127.2\left(\mathrm{C}_{12}\right), 125.7\left(\mathrm{C}_{15}\right), 124.97$ (C 14$), 124.93\left(\mathrm{C}_{10}\right), 124.8\left(\mathrm{C}_{16}\right), 124.6\left(\mathrm{C}_{17}\right), 120.8\left(\mathrm{C}_{4}\right)$. HRMS (MALDI-TOF) m/z: [M+H] ${ }^{+}$calcd for $\mathrm{C}_{172} \mathrm{H}_{92} \mathrm{~N}_{4} \mathrm{Zn} 2277.6652$; Found: $2277.668(1.5 \mathrm{ppm}$ error). UV/vis (toluene): $\lambda 280(\varepsilon=274000), 350(\varepsilon=208000), 415(\varepsilon=81000), 432(\varepsilon=442000)$, $551(\varepsilon=23000)$

\section{$\mathrm{ZnPOBr}$}

2HPOBr (60 mg, $0.048 \mathrm{mmol})$ and $\mathrm{Zn}(\mathrm{AcO})_{2} \cdot 2 \mathrm{H}_{2} \mathrm{O}(84 \mathrm{mg}, 0.382 \mathrm{mmol})$ were mixed in a sealed vessel specifically designed for microwave irradiation, and $1.5 \mathrm{ml}$ of $\mathrm{CHCl}_{3}$ was added. The mixture was stirred inside the microwave reactor at $150{ }^{\circ} \mathrm{C}$ for $150 \mathrm{~min}$; the pressure reached up to 10 bar. Subsequently, the crude was dissolved in $20 \mathrm{ml}$ of $\mathrm{CHCl}_{3}$, placed in a separatory funnel, and washed with $10 \mathrm{ml}$ of $\mathrm{H}_{2} \mathrm{O}$. The organic layer was removed under low pressure to give the purple solid $\mathbf{Z n P O B r}$ (56 mg, 89\% yield). ${ }^{1} \mathrm{H}$ NMR (500 MHz, Chloroform- $d$ ): $\delta 8.99\left(\mathrm{~s}, 8 \mathrm{H}, \mathrm{H}_{2}\right), 8.31$ (d, $\left.J=1.8 \mathrm{~Hz}, 8 \mathrm{H}, \mathrm{H}_{6}\right), 8.15(\mathrm{t}, J=1.8 \mathrm{~Hz}, 4 \mathrm{H}$, $\left.\mathrm{H}_{8}.\right) .{ }^{13} \mathrm{C}\left\{{ }^{1} \mathrm{H}\right\}$ NMR (126 MHz, Chloroform-d): $\delta 149.9\left(\mathrm{C}_{3}\right), 135.8\left(\mathrm{C}_{6}\right), 133.7\left(\mathrm{C}_{8}\right), 132.3\left(\mathrm{C}_{2}\right), 121.4\left(\mathrm{C}_{7}-\mathrm{in}\right), 118.4\left(\mathrm{C}_{4}\right.$-in). HRMS (MALDI-TOF) m/z: [M+H] ${ }^{+}$Calcd for $\mathrm{C}_{44} \mathrm{H}_{20} \mathrm{Br}_{8} \mathrm{~N}_{4} \mathrm{Zn} 1309.4344$; Found: 1309.4372 (2.1 ppm error). UV/vis (toluene): $\lambda 401(\varepsilon=24400), 424(\varepsilon=160981), 515(\varepsilon=6428), 550(\varepsilon=6100), 587(\varepsilon=2529)$. 
ZnPOBr (30 mg, $0.023 \mathrm{mmol}$ ), bis(pinacolato)diboron (70 mg, $0.276 \mathrm{mmol})$, [ $\left.\mathrm{PdCl}_{2}(\mathrm{dpp})\right]$ (6.7 mg, $\left.0.0092 \mathrm{mmol}\right)$, and AcOK (54.16 mg, $0.552 \mathrm{mmol}$ ) were mixed in a sealed vessel specifically designed for microwave irradiation. The microwave Vessel was placed inside a two-necked round-bottom flask in order to keep the system under an inert atmosphere. 0.7 ml of dry dioxane and $35 \mu \mathrm{l}$ of pyridine were then added to the microwave vessel. The mixture was stirred inside the microwave reactor at $160{ }^{\circ} \mathrm{C}$ for $150 \mathrm{~min}$; the pressure reached 3 bar. Subsequently, the solvent was removed under vacuum and the obtained solid was dissolved in $20 \mathrm{ml}$ of $\mathrm{CHCl}_{3}$, placed in a separatory funnel, and washed with $10 \mathrm{ml}$ of $\mathrm{H}_{2} \mathrm{O}$. The solvent was evaporated from the deep red organic layer, and the obtained solid was transferred to a centrifugation vial and underwent five wash-centrifuge cycles with hexane to finally afford the purple solid ZnPOB (27 mg, 71\% yield). ${ }^{1} \mathrm{H}$ NMR (500 MHz, Chloroform-d): $\delta 8.85$ (s, $8 \mathrm{H}$, $\mathrm{H}_{2}$ ), $8.73\left(\mathrm{~d}, J=1.2 \mathrm{~Hz}, 8 \mathrm{H}, \mathrm{H}_{6}\right), 8.64\left(\mathrm{t}, J=1.2 \mathrm{~Hz}, 4 \mathrm{H}, \mathrm{H}_{8}\right), 1.36\left(\mathrm{~s}, 96 \mathrm{H}, \mathrm{H}_{10}\right) .{ }^{13} \mathrm{C}\left\{{ }^{1} \mathrm{H}\right\}$ NMR (126 MHz, Chloroform-d) $\delta$ : $150.2\left(\mathrm{C}_{3}\right), 142.8\left(\mathrm{C}_{6}\right), 141.7\left(\mathrm{C}_{5}\right), 140.0\left(\mathrm{C}_{8}\right), 132.0\left(\mathrm{C}_{2}\right), 126.2\left(\mathrm{C}_{7}\right), 120.9\left(\mathrm{C}_{4}\right), 83.8\left(\mathrm{C}_{9}\right), 24.9\left(\mathrm{C}_{10}\right)$. HRMS (MALDI-TOF) $\mathrm{m} / \mathrm{z}:[\mathrm{M}+\mathrm{H}]^{+}$Calcd for $\mathrm{C}_{92} \mathrm{H}_{116} \mathrm{~B}_{8} \mathrm{~N}_{4} \mathrm{O}_{16} \mathrm{Zn1683.8502}$; Found 1683.8619 (11.7 ppm error). UV/vis (toluene): $\lambda 405$ ( $\left.\varepsilon=22741\right)$, $426(\varepsilon=186524), 550(\varepsilon=12414)$.

2HPOB

2HPOBr (20 mg, $0.016 \mathrm{mmol})$, bis(pinacolato)diboron (48.75 mg, $0.192 \mathrm{mmol}),\left[\mathrm{PdCl}_{2}(\mathrm{dppf})\right](4.68 \mathrm{mg}, 0.0064 \mathrm{mmol})$, and AcOK (36.9 mg, $0.384 \mathrm{mmol}$ ) were mixed into a sealed vessel specifically designed for microwave irradiation. The microwave vessel was placed inside a two-necked round-bottom flask in order to keep the system under an inert atmosphere. 0.5 ml of dry dioxane was then added to the microwave vessel. The mixture was stirred inside the microwave reactor at $160{ }^{\circ} \mathrm{C}$ for 150 min and reached a pressure of 3 bar. Subsequently, the solvent was removed under vacuum and the obtained solid was dissolved in $15 \mathrm{ml}$ of $\mathrm{CHCl}_{3}$, placed in a separatory funnel, and washed with $8 \mathrm{ml}$ of $\mathrm{H}_{2} \mathrm{O}$. The solvent of the deep red organic layer was evaporated. The obtained solid was transferred to a centrifugation vial and underwent five washing-centrifugation cycles with hexane (5 times) to finally afford the purple solid 2HPOB (19 mg, 73\% yield). ${ }^{1} \mathrm{H}$ NMR (500 MHz, Chloroform- $d$ ): $\delta 8.76$ (s, $\left.8 \mathrm{H}, \mathrm{H}_{2}\right), 8.71\left(\mathrm{~d}, J=1.2 \mathrm{~Hz}, 8 \mathrm{H}, \mathrm{H}_{6}\right), 8.65\left(\mathrm{t}, J=1.2 \mathrm{~Hz}, 4 \mathrm{H}, \mathrm{H}_{8}\right), 1.36\left(\mathrm{~s}, 96 \mathrm{H}, \mathrm{H}_{10}\right),-2.79\left(\mathrm{br}, 2 \mathrm{H}, \mathrm{H}_{1}\right) .{ }^{13} \mathrm{C}\left\{{ }^{1} \mathrm{H}\right\} \mathrm{NMR}(126$ MHz, Chloroform-d): $\delta 142.8\left(\mathrm{C}_{6}\right), 141.0\left(\mathrm{C}_{5}\right), 140.3\left(\mathrm{C}_{8}\right), 131.3\left(\mathrm{C}_{2}\right), 126.4\left(\mathrm{C}_{7}\right), 120.0\left(\mathrm{C}_{4}\right), 83.9\left(\mathrm{C}_{9}\right), 24.9\left(\mathrm{C}_{10}\right) . \mathrm{HRMS}$ (MALDI-TOF) m/z: [M+H] $]^{+}$Calcd for $\mathrm{C}_{92} \mathrm{H}_{118} \mathrm{~B}_{8} \mathrm{~N}_{4} \mathrm{O}_{16}$ 1622.9443; Found: 1622.9426 (-1.7 ppm error). UV/vis (toluene): $\lambda$ 407 $(\varepsilon=59125), 422(\varepsilon=298419), 515(\varepsilon=12104), 548(\varepsilon=3957)$.

\section{ASSOCIATED CONTENT}

\section{Supporting Information}

The Supporting Information is available free of charge on the ACS Publications website. Spectra of compounds are provided in PDF format.

\section{AUTHOR INFORMATION}

\section{Corresponding Author}


Celedonio M. Álvarez: GIR MIOMeT, IU CINQUIMA/Química Inorgánica, Facultad de Ciencias, Universidad de Valladolid, E47011, Valladolid, Spain.

E-mail: celedonio.alvarez@uva.es

Raul Garcia-Rodriguez GIR MIOMeT, IU CINQUIMA/Química Inorgánica, Facultad de Ciencias, Universidad de Valladolid, E47011, Valladolid, Spain.

E-mail: raul.garcia.rodriguez@uva.es

\section{Notes}

The authors declare no competing financial interests.

\section{ACKNOWLEDGMENT}

This research was supported by the Spanish Ministerio de Economía y Competitividad (MINECO) (project number CTQ 2013-41067-P). R.G.-R. acknowledges the Spanish MINECO - AEI and the European Union (ESF) for a Ramon y Cajal contract (RYC-2015-19035). H. B. acknowledges the Alfonso Martín Escudero Foundation for a postdoctoral fellowship.

\section{REFERENCES}

(1) Pérez, E. M.; Martín, N. $\pi$ - $\pi$ Interactions in Carbon Nanostructures. Chem. Soc. Rev. 2015, 44, 6425-6433.

(2) Pérez, E. M.; Martín, N. Curves Ahead: Molecular Receptors for Fullerenes Based on Concave-Convex Complementarity. Chem. Soc. Rev. 2008, 37, 1512-1519.

(3) (a) Scott, L. T.; Hashemi, M. M.; Bratcher, M. S. Corannulene Bowl-to-Bowl Inversion Is Rapid at Room Temperature. J. Am. Chem. Soc. 1992, 114, 1920-1921.(b) Wu, Y.-T.; Siegel, J. S. Aromatic Molecular-Bowl Hydrocarbons: Synthetic Derivatives, Their Structures, and Physical Properties. Chem. Rev. 2006, 106, 4843-4867.(c) Li, X.; Kang, F.; Inagaki, M. Buckybowls: Corannulene and Its Derivatives. Small 2016, 12, 3206-3223. (d) Saito, M.; Shinokubo, H.; Sakurai, H. Figuration of Bowl-Shaped $\pi$-Conjugated Molecules: Properties and Functions. Materials Chemistry Frontiers 2018, 2, 635-661.(e) Nestoros, E.; Stuparu, M. C. Corannulene: A Molecular Bowl of Carbon with Multifaceted Properties and Diverse Applications. Chem. Commun. 2018, 54, 6503-6519.

(4) (a) Ehli, C.; Rahman, G. M. A.; Jux, N.; Balbinot, D.; Guldi, D. M.; Paolucci, F.; Marcaccio, M.; Paolucci, D.; Melle-Franco, M.; Zerbetto, F.; Campidelli, S.; Prato, M. Interactions in Single Wall Carbon Nanotubes/Pyrene/Porphyrin Nanohybrids. J. Am. Chem. Soc. 2006, 128, 11222-11231. (b) Zhao, Y.-L.; Hu, L.; Grüner, G.; Stoddart, J. F. A Tunable Photosensor. J. Am. Chem. Soc. 2008, 130, 1699617003. (c) Zhao, Y.-L.; Stoddart, J. F. Noncovalent Functionalization of Single-Walled Carbon Nanotubes. Acc. Chem. Res. 2009, 42, 1161-1171. (d) Bilalis, P.; Katsigiannopoulos, D.; Avgeropoulos, A.; Sakellariou, G. Non-covalent Functionalization of Carbon Nanotubes with Polymers. RSC Advances 2014, 4, 2911-2934. (e) de Juan, A.; López-Moreno, A.; Calbo, J.; Ortí, E.; Pérez, E. M. Determination of Association Constants towards Carbon Nanotubes. Chem. Sci. 2015, 6, 7008-7014. (f) López-Moreno, A.; Pérez, E. M. Pyrene-based Mechanically Interlocked SWNTs. Chem. Commun. 2015, 51, 5421-5424. (g) Calbo, J.; López-Moreno, A.; de Juan, A.; Comer, J.; Ortí, 
E.; Pérez , E. M. Understanding Noncovalent Interactions of Small Molecules with Carbon Nanotubes. Chemistry - A European Journal 2017, 23, 12909-12916.

(5) (a) Zhang, M.; Parajuli, R. R.; Mastrogiovanni, D.; Dai, B.; Lo, P.; Cheung, W.; Brukh, R.; Chiu, P. L.; Zhou, T.; Liu, Z.; Garfunkel, E.; He, H. Production of Graphene Sheets by Direct Dispersion with Aromatic Healing Agents. Small 2010, 6, 1100-1107. (b) Mann, J. A.; Rodríguez-López, J.; Abruña, H. D.; Dichtel, W. R. Multivalent Binding Motifs for the Noncovalent Functionalization of Graphene. J. Am. Chem. Soc. 2011, 133, 17614-17617. (c) Ciesielski, A.; Samori, P. Graphene via Sonication Assisted Liquid-Phase Exfoliation. Chem. Soc. Rev. 2014, 43, 381-398. (d) KC, C. B.; Lim, G. N.; D'Souza, F. Charge Separation in Graphene-Decorated Multimodular Tris(pyrene)Subphthalocyanine-Fullerene Donor-Acceptor Hybrids. Angew. Chem. Int. Ed. 2015, 54, 5088-5092. (e) Ciesielski, A.; Samorì, P. Supramolecular Approaches to Graphene: From Self-Assembly to Molecule-Assisted Liquid-Phase Exfoliation. Adv. Mater. 2016, 28, 60306051. (f) Bottari, G.; Herranz, M. Á.; Wibmer, L.; Volland, M.; Rodríguez-Pérez, L.; Guldi, D. M.; Hirsch, A.; Martín, N.; D'Souza, F.; Torres, T. Chemical Functionalization and Characterization of Graphene-Based Materials. Chem. Soc. Rev. 2017, 46, 4464-4500. (g) Garrido, M.; Calbo, J.; Rodríguez-Pérez, L.; Aragó, J.; Ortí, E.; Herranz, M. A.; Martín, N. Non-covalent Graphene Nanobuds from Monoand Tripodal Binding Motifs. Chem. Commun. 2017, 53, 12402-12405.

(6) Mulla, K.; Shaik, H.; Thompson, D. W.; Zhao, Y. TTFV-Based Molecular Tweezers and Macrocycles as Receptors for Fullerenes. Org. Lett. 2013, 15, 4532-4535.

(7) (a) Ronson, T. K.; League, A. B.; Gagliardi, L.; Cramer, C. J.; Nitschke, J. R. Pyrene-Edged Fe ${ }_{4}^{\mathrm{II}} \mathrm{L}_{6}$ Cages Adaptively Reconfigure during Guest Binding. J. Am. Chem. Soc. 2014, 136, 15615-15624. (b) Ronson, T. K.; Meng, W.; Nitschke, J. R. Design Principles for the Optimization of Guest Binding in Aromatic-Paneled Fe ${ }_{4}{ }_{4}{ }_{6}$ Cages. J. Am. Chem. Soc. 2017, 139, 9698-9707.

(8) (a) Álvarez, C. M.; García-Escudero, L. A.; García-Rodríguez, R.; Martín-Álvarez, J. M.; Miguel, D.; Rayón, V. M. Enhanced Association for $\mathrm{C}_{70}$ over $\mathrm{C}_{60}$ with a Metal Complex with Corannulene Derivate Ligands. Dalton Transactions 2014, 43, 15693-15696. (b) Abeyratne Kuragama, P. L.; Fronczek, F. R.; Sygula, A. Bis-corannulene Receptors for Fullerenes Based on Klärner’s Tethers: Reaching the Affinity Limits. Org. Lett. 2015, 17, 5292-5295. (c) Yang, D.-C.; Li, M.; Chen, C.-F. A Bis-corannulene Based Molecular Tweezer with Highly Sensitive and Selective Complexation of $C_{70}$ over $C_{60}$. Chem. Commun. 2017, 53, 9336-9339.

(9) (a) Sygula, A.; Fronczek, F. R.; Sygula, R.; Rabideau, P. W.; Olmstead, M. M. A Double Concave Hydrocarbon Buckycatcher. J. Am. Chem. Soc. 2007, 129, 3842-3843. (b) Stuparu, M. C. Rationally Designed Polymer Hosts of Fullerene. Angew. Chem. Int. Ed. 2013, 52, 7786-7790. (c) Le, V. H.; Yanney, M.; McGuire, M.; Sygula, A.; Lewis, E. A. Thermodynamics of Host-Guest Interactions between Fullerenes and a Buckycatcher. J. Phys. Chem. B. 2014, 118, 11956-11964. (d) Yanney, M.; Fronczek, F. R.; Sygula, A. A 2:1 Receptor/C 60 Complex as a Nanosized Universal Joint. Angew. Chem. Int. Ed. 2015, 54, 11153-11156. (e) Kumarasinghe, K. G. U. R.; Fronczek, F. R.; Valle, H. U.; Sygula, A. Bis-corannulenoanthracene: An Angularly Fused Pentacene as a Precursor for Barrelene-Tethered Receptors for Fullerenes. Org. Lett. 2016, 18, 3054-3057. (f) Barbero, H.; Ferrero, S.; Álvarez-Miguel, L.; Gómez-Iglesias, P.; Miguel, D.; Álvarez, C. M. Affinity Modulation of Photoresponsive Hosts for Fullerenes: Light-Gated Corannulene Tweezers. Chem. Commun. 2016, 52, 1296412967.

(10) (a) Boyd, P. D. W.; Hodgson, M. C.; Rickard, C. E. F.; Oliver, A. G.; Chaker, L.; Brothers, P. J.; Bolskar, R. D.; Tham, F. S.; Reed, C. A. Selective Supramolecular Porphyrin/Fullerene Interactions. J. Am. Chem. Soc. 1999, 121, 10487-10495.(b) Olmstead, M. M.; Costa, 
D. A.; Maitra, K.; Noll, B. C.; Phillips, S. L.; Van Calcar, P. M.; Balch, A. L. Interaction of Curved and Flat Molecular Surfaces. The Structures of Crystalline Compounds Composed of Fullerene $\left(\mathrm{C}_{60}, \mathrm{C}_{60} \mathrm{O}, \mathrm{C}_{70}\right.$, and $\left.\mathrm{C}_{120} \mathrm{O}\right)$ and Metal Octaethylporphyrin Units. J. Am. Chem. Soc. 1999, 121, 7090-7097. (c) Boyd, P. D. W.; Reed, C. A. Fullerene-Porphyrin Constructs. Acc. Chem. Res. 2005, 38, $235-242$. (d) Bhyrappa, P.; Karunanithi, K. Porphyrin-Fullerene, $\mathrm{C}_{60}$, Cocrystallates: Influence of $\mathrm{C}_{60}$ on the Porphyrin Ring Conformation. Inorg. Chem. 2010, 49, 8389-8400. (e) Bhyrappa, P.; Sarangi, U. K.; Varghese, B. Switching the Macrocycle Conformation from Nonplanar to Planar in Cobalt(II) and Copper(II) $\beta$-Tetra-2'-thienyl-meso-tetraphenylporphyrin Cocrystallates with $\mathrm{C}_{60}$. Eur. J. Inorg. Chem. 2014, $2014,5646-5650$.

(11) (a) Tashiro, K.; Aida, T. Metalloporphyrin Hosts for Supramolecular Chemistry of Fullerenes. Chem. Soc. Rev. 2007, 36, 189-197. (b) Bromby, A. D.; Hogan, D. T.; Sutherland, T. C. Core Expanded, 21,23-Dithiadiacenaphtho[1,2-c]porphyrin Interactions with [60]Fullerene. New J. Chem. 2017, 41, 4802-4805.

(12) Durot, S.; Taesch, J.; Heitz, V. Multiporphyrinic Cages: Architectures and Functions. Chem. Rev. 2014, 114, 8542-8578.

(13) (a) Canevet, D.; Pérez, E. M.; Martín, N. Wraparound Hosts for Fullerenes: Tailored Macrocycles and Cages. Angew. Chem. Int. Ed. 2011, 50, 9248-9259. (b) Jurow, M.; Farley, C.; Pabon, C.; Hageman, B.; Dolor, A.; Drain, C. M. Facile Synthesis of a Flexible Tethered Porphyrin Dimer That Preferentially Complexes Fullerene $C_{70}$. Chem. Commun. 2012, 48, 4731-4733. (c) García-Simón, C.; GarciaBorràs, M.; Gómez, L.; Parella, T.; Osuna, S.; Juanhuix, J.; Imaz, I.; Maspoch, D.; Costas, M.; Ribas, X. Sponge-like Molecular Cage for Purification of Fullerenes. Nature Communications 2014, 5, 5557. (d) Fang, X.; Zhu, Y.-Z.; Zheng, J.-Y. Clawlike Tripodal Porphyrin Trimer: Ion-Controlled On-Off Fullerene Binding. J. Org. Chem. 2014, 79, 1184-1191. (e) García-Simón, C.; Costas, M.; Ribas, X. Metallosupramolecular Receptors for Fullerene Binding and Release. Chem. Soc. Rev. 2016, 45, 40-62.

(14) Álvarez, C. M.; Barbero, H.; Ferrero, S.; Miguel, D. Synergistic Effect of Tetraaryl Porphyrins Containing Corannulene and Other Polycyclic Aromatic Fragments as Hosts for Fullerenes. Impact of $\mathrm{C}_{60}$ in a Statistically Distributed Mixture of Atropisomers. J. Org. Chem. 2016, 81, 6081-6086.

(15) (a) Kimura, M.; Shiba, T.; Muto, T.; Hanabusa, K.; Shirai, H. Intramolecular Energy Transfer in 1,3,5-Phenylene-Based Dendritic Porphyrins. Macromolecules 1999, 32, 8237-8239. (b) Kimura, M.; Shiba, T.; Yamazaki, M.; Hanabusa, K.; Shirai, H.; Kobayashi, N. Construction of Regulated Nanospace around a Porphyrin Core. J. Am. Chem. Soc. 2001, 123, 5636-5642.

(16) Kappe, C. O. Controlled Microwave Heating in Modern Organic Synthesis. Angew. Chem. Int. Ed. 2004, 43, 6250-6284.

(17) Yao, D.; Zhang, X.; Mongin, O.; Paul, F.; Paul-Roth, C. O. Synthesis and Characterization of New Conjugated Fluorenyl-Porphyrin Dendrimers for Optics. Chemistry - A European Journal 2016, 22, 5583-5597.

(18) (a) Lemon, C. M.; Brothers, P. J.; Boitrel, B. Porphyrin Complexes of the Period 6 Main Group and Late Transition Metals. Dalton Transactions 2011, 40, 6591-6609. (b) Kadish, K. M.; Smith, K. M.; Guilard, R. Handbook of Porphyrin Science (Volumes 21- 25); World Scientific Publishing Company, 2012; Vol. Volumes 21 - 25. (c) Valicsek, Z.; Horváth, O. Application of the Electronic Spectra of Porphyrins for Analytical Purposes: The Effects of Metal Ions and Structural Distortions. Microchem. J. 2013, 107, 47-62. (d) Senge, M. O.; MacGowan, S. A.; O'Brien, J. M. Conformational Control of Cofactors in Nature - The Influence of Protein-Induced Macrocycle Distortion on the Biological Function of Tetrapyrroles. Chem. Commun. 2015, 51, 17031-17063. 
(19) (a) Jian-Yu, Z.; Kentaro, T.; Yusuke, H.; Kazushi, K.; Kazuhiko, S.; Takuzo, A.; Shigeru, S.; Kentaro, Y. Cyclic Dimers of Metalloporphyrins as Tunable Hosts for Fullerenes: A Remarkable Effect of Rhodium(III). Angew. Chem. Int. Ed. 2001, 40, 1857-1861. (b) Sun, D.; Tham, F. S.; Reed, C. A.; Chaker, L.; Boyd, P. D. W. Supramolecular Fullerene-Porphyrin Chemistry. Fullerene Complexation by Metalated “Jaws Porphyrin” Hosts. J. Am. Chem. Soc. 2002, 124, 6604-6612. (c) Wang, Y.-B.; Lin, Z. Supramolecular Interactions between Fullerenes and Porphyrins. J. Am. Chem. Soc. 2003, 125, 6072-6073. (d) Ayako, O.; Kentaro, T.; Kentaro, Y.; Takahiro, T.; Takeshi, A.; Takuzo, A. A Self-Regulatory Host in an Oscillatory Guest Motion: Complexation of Fullerenes with a Short-Spaced Cyclic Dimer of an Organorhodium Porphyrin. Angew. Chem. Int. Ed. 2006, 45, 3542-3546. (e) Yanagisawa, M.; Tashiro, K.; Yamasaki, M.; Aida, T. Hosting Fullerenes by Dynamic Bond Formation with an Iridium Porphyrin Cyclic Dimer: A “Chemical Friction" for Rotary Guest Motions. J. Am. Chem. Soc. 2007, 129, 11912-11913.

(20) (a) A. Shelnutt, J.; Song, X.-Z.; Ma, J.-G.; Jia, S.-L.; Jentzen, W.; J. Medforth, C.; J. Medforth, C. Nonplanar Porphyrins and Their Significance in Proteins. Chem. Soc. Rev. 1998, 27, 31-42. (b) Haddad, R. E.; Gazeau, S.; Pécaut, J.; Marchon, J.-C.; Medforth, C. J.; Shelnutt, J. A. Origin of the Red Shifts in the Optical Absorption Bands of Nonplanar Tetraalkylporphyrins. J. Am. Chem. Soc. 2003, 125, 1253-1268. (c) Senge, M. O. Exercises in Molecular Gymnastics-Bending, Stretching and Twisting Porphyrins. Chem. Commun. 2006, 0, 243-256.

(21) (a) Hunter, C. A.; Sanders, J. K. M. The Nature of $\pi$ - $\pi$. Interactions. J. Am. Chem. Soc. 1990, 112, 5525-5534. (b) Saegusa, Y.; Ishizuka, T.; Kojima, T.; Mori, S.; Kawano, M.; Kojima, T. Supramolecular Interaction of Fullerenes with a Curved $\pi$-Surface of a Monomeric Quadruply Ring-Fused Porphyrin. Chemistry - A European Journal 2015, 21, 5302-5306.

(22) Thordarson, P. In Supramolecular Chemistry: From Molecules to Nanomaterials; Gale , P. A., Steed, J. W., Eds.; John Wiley \& Sons: Chichester, UK, 2012; Vol. 2, p 239-274.

(23) (a) Thordarson, P. Determining Association Constants from Titration Experiments in Supramolecular Chemistry. Chem. Soc. Rev. 2011, 40, 1305-1323. (b) Brynn Hibbert, D.; Thordarson, P. The Death of the Job Plot, Transparency, Open Science and Online Tools, Uncertainty Estimation Methods and Other Developments in Supramolecular Chemistry Data Analysis. Chem. Commun. 2016, 52, 1279212805.

(24) (a) Yanney, M.; Sygula, A. Tridental Molecular Clip with Corannulene Pincers: Is Three Better Than Two? Tetrahedron Lett. 2013, 54, 2604-2607. (b) Álvarez, C. M.; Aullón, G.; Barbero, H.; García-Escudero, L. A.; Martínez-Pérez, C.; Martín-Álvarez, J. M.; Miguel, D. Assembling Nonplanar Polyaromatic Units by Click Chemistry. Study of Multicorannulene Systems as Host for Fullerenes. Org. Lett. 2015, 17, 2578-2581.

(25) (a) Taylor, R.; Hare, J. P.; Abdul-Sada, A. a. K.; Kroto, H. W. Isolation, Separation and Characterisation of the Fullerenes ${ }_{60}$ and $\mathrm{C}_{70}$ : The Third Form of Carbon. J. Chem. Soc., Chem. Commun. 1990, 0, 1423-1425. (b) Ajie, H.; Alvarez, M. M.; Anz, S. J.; Beck, R. D.; Diederich, F.; Fostiropoulos, K.; Huffman, D. R.; Kraetschmer, W.; Rubin, Y.; et al. Characterization of the Soluble All-Carbon Molecules $\mathrm{C}_{60}$ and $\mathrm{C}_{70}$. The Journal of Physical Chemistry 1990, 94, 8630-8633. (c) Diederich, F.; Whetten, R. L. Beyond $\mathrm{C}_{60}$ : The Higher Fullerenes. Acc. Chem. Res. 1992, 25, 119-126.

(26) Hare, J. P.; Kroto, H. W.; Taylor, R. Reprint of: Preparation and UV/visible Spectra of Fullerenes $\mathrm{C}_{60}$ and $\mathrm{C}_{70}$. Chem. Phys. Lett. 2013, 589, 57-60. 
(27) (a) Zhang, C.; Wang, Q.; Long, H.; Zhang, W. A highly $\mathrm{C}_{70}$ selective shape-persistent rectangular prism constructed through one-step alkyne metathesis. J. Am. Chem. Soc. 2011, 133, 20995-21001. (b) Shi, Y.; Cai, K.; Xiao, H.; Liu, Z.; Zhou, J.; Shen, D.; Qiu, Y.; Guo, Q. H.; Stern, C.; Wasielewski, M. R.; Diederich, F.; Goddard, W. A., Stoddart, J. F. Selective Extraction of C $_{70}$ by a Tetragonal Prismatic Porphyrin Cage. J. Am. Chem. Soc. 2018, 140, 13835-13842.

(28) (a) Armarego, W. L. F.; Chai, C. L. L. Purification of Laboratory Chemicals, 6th; Butterworth-Heinemann: London, 2009. (b) Williams, D. B. G.; Lawton, M. Drying of Organic Solvents: Quantitative Evaluation of the Efficiency of Several Desiccants. J. Org. Chem. 2010, 75, 8351-8354.

(29) Matthias, B.; Wilfried, W.; Martin, J.; Wolfgang, R.; Claudia, M.; Irene, B.; Hans, H.; A. Dieter, S. Synthesis and Spectroscopic Properties of Arene-Substituted Pyrene Derivatives as Model Compounds for Fluorescent Polarity Probes. Eur. J. Org. Chem. 2001, 2001, 3819-3829. 
Table of Contents artwork

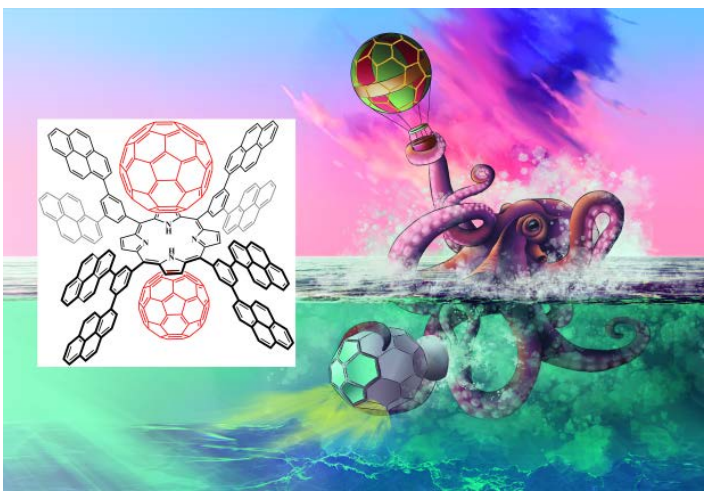

